\title{
Ribotyping of Salmonella Enteritidis strains reveals the spread of a single genotype in the Brazilian city of Ribeirão Preto
}

\author{
Ribotipagem de cepas de Salmonella Enteritidis revela a propagação de um único genótipo na \\ cidade de Ribeirão Preto
}

Carlos Henrique Gomes Martins'; Vanda Roseli dos Santos 2 ; Fabíola Attié de Castro ${ }^{3}$; Sueli Aparecida Fernandes ${ }^{4}$, Roberto Martinez ${ }^{5}$

\begin{abstract}
key words abstract Ribotyping

Salmonella Enteritidis

Background: The approach generally employed in leading laboratories worldwide to identify strains of Salmonella is to detect epidemiological markers by serotyping and molecular techniques. These molecular methods are important in sanitary surveillance and lead to the source of infection. Objectives: The aim of the present study is to characterize Salmonella Enteritidis strains by ribotyping. Material and methods: Thirty-eight strains of $S$. Enteritidis were isolated from in patients at the university hospital of Universidade de São Paulo, Ribeirão Preto, SP, Brazil, between 1996 and 1998. These strains were isolated from stools (31 samples), blood (4 samples) and other body fluids (3 samples), using routine bacteriological methods, and were serotyped and ribotyped. Results: The 38 strains of serotype S. Enteritidis were shown by the ribotyping to belong to two ribotypes: A ( $94.7 \%$ of the samples) and B (5.3\%). Discussion and conclusion: These results suggest that the majority of patients $(94.7 \%)$ were infected by the same strain. This strain could be endemic in the Ribeirão Preto community, or these patients may have been exposed to a common source of infection.
\end{abstract}

\section{resumo}

Introdução: Na identificação de cepas de Salmonella, os métodos de sorotipagem e ribotipagem na detecção de marcadores epidemiológicos são os mais utilizados nos laboratórios de referência mundiais. Esses métodos moleculares são imprescindíveis na vigilância epidemiológica e permitem a detecção da fonte da infecção. Objetivos: O presente trabalho objetivou caracterizar as cepas de Salmonella Enteritidis pela ribotipagem. Material e métodos: Trinta e oito cepas de S. Enteritidis foram isoladas de pacientes atendidos no Hospital das Clínicas da Universidade de São Paulo, Ribeirão Preto, SP, entre os anos de 1996 e 1998. As cepas foram isoladas de fezes (31 amostras), sangue (quatro amostras) e outros fluidos (três amostras). As cepas de Salmonella foram isoladas utilizando-se métodos bacteriológicos de rotina, sorotipadas e ribotipadas. Resultados: As 38 cepas de S. Enteritidis apresentaram na ribotipagem a separação das cepas em dois ribotipos: $A$ ( $94,7 \%$ das amostras) $e$ $B$ (5,3\% das amostras). Discussão e conclusão: Esses dados sugerem que grande parte dos pacientes (94,7\%) foi infectada pela mesma cepa. Essa cepa pode ser endêmica na comunidade de Ribeirão Preto ou os pacientes foram expostos a uma fonte comum de infecção. unitermos

Ribotipagem

Salmonella Enteritidis

1. Professor at Faculdade de Biomedicina, Universidade de Franca.

2. Biologist at the milk bank of the university hospital of Faculdade de Medicina de Ribeirão Preto of Universidade de São Paulo (FMRP/USP).

3. Professor at Departamento de Análises Clínicas Toxicológicas e Bromatológicas of Faculdade de Ciências Farmacêuticas de Ribeirão Preto, USP.

4. Researcher at Instituto Adolfo Lutz, São Paulo.

5. Associate professor at Departamento de Clínica Médica of FMRP/USP. 


\section{Introduction}

Non-typhoid salmonellosis is one of the commonest foodborne diseases and most frequently reported bacterial infections. The usual causative agent of this disease is Salmonella typhimurium or the emerging pathogen $S$. Enteritidis ${ }^{(1)}$. In the last decade the incidence of gastrointestinal infections caused by $S$. Enteritidis has increased ${ }^{(16,21)}$; outbreaks have been reported in the United States and Europe since the 1970s ${ }^{(3)}$. Also, in many developing countries, such as Brazil, foodborne outbreaks and nosocomial infections caused by Salmonella enterica subsp. enterica serotype Enteritidis (S. Enteritidis) remain an important public health problem. In the emergency unit at the university hospital of Faculdade de Medicina de Ribeirão Preto of Universidade de São Paulo (FMRP/USP), during the years 1985-1999, S. Enteritidis exhibited a steady and significant rise, becoming the most frequently isolated Salmonella serotype in $1998^{(6)}$. This increase could be linked to a rapid growth of the international trade of food products, changes in the type of food consumed, food contamination and salmonellosis in acquired immunodeficiency syndrome patients.

The worldwide rise of $S$. Enteritidis nowadays constitutes a public health concern; it is a challenge to epidemiologist and clinical staff alike ${ }^{(22,24)}$. The main approach taken to control the dissemination of salmonellosis is to employ molecular techniques. Methods based on DNA restriction analysis, such as ribotyping, can discriminate Salmonella strains involved in human infection and give information on the epidemiological and genetic relationship among serotypes. Hence, to differentiate serotypes such as $S$. Enteritidis, ribotyping has been employed in epidemiological investigation all over the world $(2,9,10)$.

The aim of this study was to analyze the rRNA gene restriction pattern of the $S$. Enteritidis strains isolated from patients at the university hospital of FMRP/USP, between 1996 and 1998.

\section{Material and methods}

A total of 83 strains of Salmonella (9.5\%) were isolated from 872 patients admitted to the university hospital of FMRP/USP, State of São Paulo, Brazil, between March 1996 and April 1998. Salmonella strains were identified by standard bacteriological methods (biochemical and agglutination methods) $)^{(7)}$ and serotyped, as detailed in Popoff and Le Minor ${ }^{(17)}$.

S. Enteritidis was the most frequently cultivated serotype from clinical samples, totalizing 38 strains (45.8\%), listed

in Table 1. Salmonella chromosomal DNA was extracted, purified, as described by Brenner et al. ${ }^{(4)}$, and digested with Sphl enzyme in accordance to manufacturer's instructions (Pharmacia Biotech, Herts, United Kingdom). Previous findings ${ }^{(14)}$ had shown that this enzyme was the best to discriminate strains of $S$. Enteritidis.

DNA fragments were separated by horizontal electrophoresis in $0.8 \%$ agarose gel (Sigma) with Tris-acetate EDTA as running buffer ${ }^{(23)}$, transferred to nylon membranes probe obtained by reverse transcription from E. colirRNA (Boerhinger Mannheim, Germany), and labeled with digoxigenin (DIG), as in Popovic et al.(18). In this method, genes are arranged in seven to eight bands (Figure 1) and a single difference in the number or position of these bands is considered as a different ribotype. DNA fragment sizes were estimated using DNA STAR software (DNA STAR Computer System for Molecular Biology and Genetics, London, UK), and Haemophilus aegyptius 3031 EcoRI DNA digest as molecular marker.

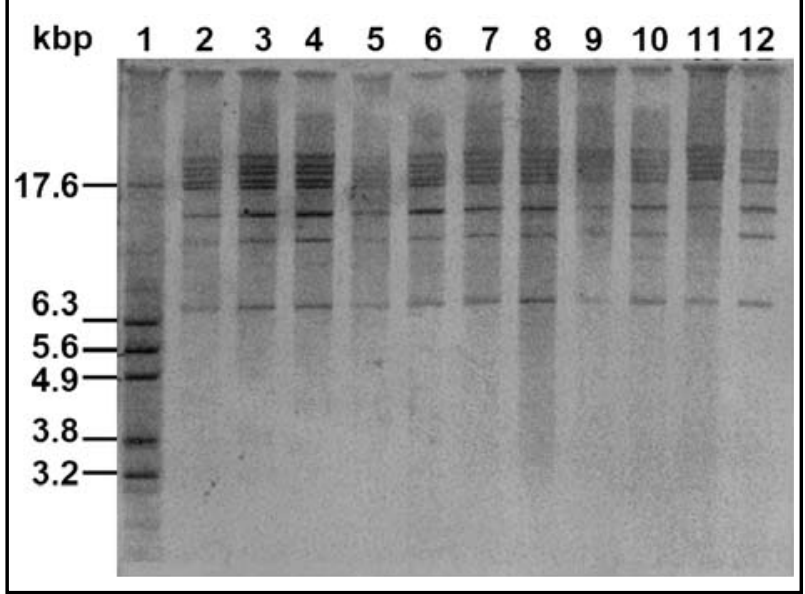

Figure 1 - Ribotypes of S. Enteritidis after hybridization with DIC-labeled 16S+23S CDNA probe. Lane 1: molecular weight marker Haemophilus aegyptius 3031 EcoRI DNA digest. Lanes 2 to 11: ribotype A, after digestion with Sphl. Lane 12: ribotype B, after digestion with Sphl

\section{Results}

The commonest occurrence of infection was in children in their first ten years. At the time of hospital admission, most patients presented acute gastroenteritis and fever. Some of the characteristics of the isolated strains, one from each patient, are displayed in Table 1.

In the ribotyping analysis following Sphl digestion, two ribotypes ( $A$ and $B$ ) were detected among the $38 \mathrm{~S}$. Enteritidis strains (Figure 1). Thirty-six strains of $S$. Enteritidis (94.7\%) had ribotype A and the other two (5.3\%) had ribotype $B$, differing from the absence of one band at a position corresponding to the $17.6 \mathrm{Kbp}$ marker. 


\section{Table 1}

\section{Characteristics and results of the ribotyping test of the 38 S. Enteritidis isolates}

Date of isolate

5/3/1996

5/27/1996

$6 / 17 / 1996$

$7 / 29 / 1996$

$8 / 6 / 1996$

9/6/1996

9/27/1996

9/30/1996

10/15/1996

$10 / 30 / 1996$

10/31/1996

11/4/1996

$11 / 5 / 1996$

11/13/1996

1/27/1997

$1 / 27 / 1997$

2/8/1997

$3 / 31 / 1997$

4/29/1997

$5 / 5 / 1997$

5/11/1997

5/19/1997

$7 / 29 / 1997$

9/22/1997

10/25/1997

$11 / 17 / 1997$

$12 / 4 / 1997$

$12 / 23 / 1997$

$12 / 23 / 1997$

$12 / 30 / 1997$

1/13/1998

1/19/1998

2/4/1998

$2 / 27 / 1998$

$3 / 2 / 1998$

$3 / 3 / 1998$

$3 / 9 / 1998$

4/25/1998

\section{Strain number}

487

490

494

496

501

502

503

504

506

509

510

512

513

514

524

529

532

547

550

551

552

553

558

566

573

577

579

583

584

587

592

605

597

600

601

602

606

611
Clinical material

Feces

Bile

Blood

Feces

Blood

Feces

Feces

Feces

Synovial fluid

Feces

Feces

Feces

Feces

Feces

Feces

Feces

Feces

Feces

Feces

Feces

Feces

Feces

Feces

Feces

Feces

Feces

Feces

Feces

Cerebrospinal fluid

Blood

Feces

Feces

Feces

Blood

Feces

Feces

Feces

Feces
Age

$2 \mathrm{y}$

$30 \mathrm{y}$

$33 \mathrm{y}$

$2 \mathrm{y}$

$5 y$

$23 y$

$1 y$

$1 y$

$35 \mathrm{y}$

$2 \mathrm{~m}$

$1 \mathrm{y}$

$11 \mathrm{y}$

N

$10 \mathrm{y}$

34y

$\mathrm{N}$

$2 \mathrm{y}$

$7 \mathrm{~m}$

$6 \mathrm{~m}$

$\mathrm{N}$

$4 \mathrm{~m}$

$7 \mathrm{~m}$

$6 \mathrm{~m}$

$\mathrm{N}$

30y

$2 \mathrm{y}$

$7 \mathrm{~m}$

$\mathrm{N}$

$27 \mathrm{y}$

$49 \mathrm{y}$

$1 y$

$3 y$

$2 \mathrm{y}$

$42 \mathrm{y}$

$29 y$

$41 \mathrm{y}$

$1 \mathrm{y}$

$3 \mathrm{~m}$
Ribotype

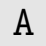

A

B

A

A

A

A

A

A

A

A

A

A

A

B

A

A

A

A

A

A

A

A

A

A

A

A

A

A

A

A

A

A

A

A

A

A

A

y: years; m: months; N: Newborn. 


\section{Discussion}

Salmonellosis continues to be the major problem for food industries and the public health system ${ }^{(6,13,21)}$. Recent data report the increasing incidence of $S$. Enteritidis strains worldwide ${ }^{(13,16,21)}$. In the state of São Paulo, a remarkable rise in the number of patients infected by $S$. Enteritidis was observed in 1993. Since 1994, it has become the most frequent serotype responsible for foodborne outbreaks and sporadic cases of human disease. There has also been an increase in the frequency with which $S$. Enteritidis has been isolated from blood cultures, mainly in children ${ }^{(9,24)}$.

Laboratory characterization of this pathogen is epidemiologically important because it helps establish the connection between clinical cases and possible sources of infection. Investigators have shown that ribotyping can differentiate Salmonella serotypes according to source, regardless of host or geographic origin ${ }^{(8)}$.

Ridley et al. ${ }^{(20)}$ and Laconha et $a^{(10)}$ investigated the genotypic differences between strains of Salmonella by plasmid analysis, ribotyping and pulsed-field gel electrophoresis (PFCE). The results obtained by those researchers indicated that PFGE may offer a better level of discrimination of $S$. Enteritidis types than other genotypic methods. Conversely, other epidemiological studies of $S$. Enteritidis have demonstrated that PFGE methodology has a lower discriminatory capacity than ribotyping $(11,12,15,19,25,26)$.

Fernandes et al. ${ }^{(9)}$ used rRNA gene restriction patterns to investigate the relatedness of $S$. Enteritidis strains isolated in São Paulo, from 1975 to 1995, and showed that ribotyping is a genomic profiling method that is reproducible and suitable for tracing the spread of $S$. Enteritidis. They found that the restriction endonuclease Sphl discriminated best between subtypes of this serotype. Thus, to discriminate $S$. Enteritidis strains in the present study, ribotyping was performed with the enzyme Sphl. This approach separated these Salmonella isolates into two ribotypes (A and B). Ribotype A was much the most prevalent and is probably endemic in the community of Ribeirão Preto. Otherwise, the infected patients were exposed to the same source of infection. This ribotype was the same as that most frequently identified among $S$. Enteritidis strains isolated in different geographic locations in São Paulo (and designated R11) ${ }^{(9)}$.

We conclude that rRNA gene-restriction patterns were used effectively to identify subtypes among Salmonella Enteritidis strains, confirming the value of ribotyping as an epidemiological tool, as well as revealing that in Riberão Preto these strains display great clonal homogeneity.

\section{References}

I.ALTEKRUSE, S.F.;SWERDLOW, D.L.The changing of epidemiology of foodborne diseases. Am J Med Sci, v. 31 I, n. I, p. 23-9, 1996.

2. ALTWEGG, M.; HICKMAN-BRENNER, F. W.; FARMER, J. J. $3^{\text {rd }}$ Ribosomal RNA gene restriction patterns provide increased sensitivity for typing Salmonella typhi strains. J Infect Dis, v. 160, n. I, p. 145-9, 1989.

3. ANGULO, F.j:; SWERDLOW, D.L. Salmonella enteritidis infections in the United States. I Am Vet Med Assoc, v. 213, n. 12, p. |729-31, 1998.

4. BRENNER, D.J. et al. Escherichia vulneris: a new species of Enterobacteriaceae associated with human wounds. I Clin Microbiol, v. 15, n. 6, p. II33-40, 1982.

5. CASTRO, F.A. et al. Prevalence and antimicrobial susceptibility of Salmonella serotypes in patients from Ribeirão Preto, São Paulo, Brazil, between 1985 and 1999. Braz J Infect Dis, v. 6 , n. 5, p. 244-5।, 2002.

6. ESTEBAN, E. et al. Use of ribotyping for the characterization of Salmonella serotypes. J Clin Microbiol, v. 3 I, n. 2, p. 233-7, 1993.

7.EWING,W.E. Edwards and Ewing's identification of Enterobacteriaceae. 4 ed. New York, N.Y.: Elsevier, 1986.

8. FERNANDES, S.A. et al. Characterization of lactose-fermenting
Salmonella agona strains isolated in a pediatric unit. Rev Microbiol, v. 28, n.4, p. 273-8, 1997

9. FERNANDES, S.A. et al. Phenotypic and molecular characterization of Salmonella enteritidis strains isolated in São Paulo, Brazil. Rev Inst Med Trop, v. 45, n. 2, p. 59-63, 2003.

10. LACONHA, I. et al. Genotypic characterization by PFGE of Salmonella enterica serotype enteritidis phage types I, 4, 6, and 8 isolated from animal and human sources in three European countries. Vet Microbiol, v. 75, p. 155-65, 2000.

I I. LANDERAS, E. et al. Epidemiological differentiation of pathogenic strains of Salmonella enteritidis by ribotyping.J Clin Microbiol, v. 34, n. 9, p. 2294-6, 1996.

12. LIEBANA, E. et al. Diversity of strains of Salmonella enterica serotype enteritidis from English poultry farms assessed by multiple genetic fingerprinting. J Clin Microbiol, v. 39, n. I, p. |54-61, 200|.

13. LOPALCO, P.L. et al. Epidemiologic study and cost analysis of a Salmonella enteritidis epidemic. Ann Ig, v. 12, n. 4, p. 279-85, 2000.

I4.MARTINETTI, G.;ALTWEGG, M.rRNA gene restriction patterns and plasmid analysis as a tool for typing Salmonella enteritidis. Res Microbiol, v. I4I, n. 9, p. I I 51-62, 1990. 
15. OLSEN, J.E. et al. Clonal lines of Salmonella enterica serotype enteritidis documented by IS200-, ribo-, pulsed-field gel electrophoresis and RFLP typing. J Med Microbiol, v. 40, n. I, p. 15-22, 1994.

16. PHILLIPS, C.A.; GEORGE, J.T. Guess what's lurking in the lunch? Biologist, v. 4I, n. I, p. 76-80, 1994.

17. POPOFF, M.Y.; Le MINOR, L. Formule antigeniques des sérovars de Salmonella. Paris. Centre Collaborateur OMS de Réference et de Recherches pour les Salmonella, Institut Pasteur, p. I 45, 1992.

18. POPOVIC, T. et al. Ribotyping in molecular epidemiology. In: PERSING, D.H. et al. (eds). Diagnostic molecular microbiology. American Society for Microbiology, Washington, D.C., 1993. p. 573-83.

19. POWELL, N.G. et al. Subdivision of Salmonella enteritidis PT4 by pulsed-field gel electrophoresis: potential for epidemiological surveillance. FEMS Microbiol Lett, v. I 19, n. I-2, p. 193-8, 1994.

20. RIDLEY, A.M.; THRELFALL, E.J.; ROWE, B. Genotypic characterization of Salmonella enteritidis phage types by plasmid analysis, ribotyping, and pulsed-field gel electrophoresis. J Clin Microbiol, v. 36, n. 8, .p. 23।4-21, 1998.

2 I. RODRIGUE, D.C.; TAUXE, R.V.; ROWE, B. International increase in Salmonella enteritidis: a new pandemic? Epidemiol Infect, $\mathrm{v}$. 105, n. I, p. 21 -7, 1990.

22. SHANKUAN, Y-H.; LIN, H-C. Application of random amplified polymorphic DNA analysis to differentiate strains of Salmonella typhi and other Salmonella species.J Appl Microbiol, v. 85, n. 4, p. 693-702, 1998.

23. SOUTHERN, E.M. Detection of specific sequences among DNA fragments separated by gel electrophoresis. J Mol Biol, v. 98, n. 3, p. 503-17, 1975.

24.TAVECHIO,A.T. et al. Changing patterns of Salmonella serovars: increase of Salmonella enteritidis in São Paulo, Brazil. Rev Inst MedTrop, v. 38, n. 5, p. 315-22, 1996.

25. THONG, K-L. et al. Molecular analysis of Salmonella enteritidis by pulsed-field gel electrophoresis and ribotyping. J Clin Microbiol, v. 33, n. 5, p. 1070-4, 1995.

26.THONG, K-L;:PUTHUCHEARY,S:PANG,T.Outbreak of Salmonella enteritidis gastroenteritis: investigation by pulsed-field gel electrophoresis. Int J Infect Dis, v. 2, n. 3, p. I59-63, 1998. 